\title{
POLITICAL ORGANIZATION IN THE PSKOV REPUBLIC: THE PRINCE, THE VECHE AND SOVEREIGNTY
}

The article analyzes the socio-political organization of the Pskov Veche republic in the $13^{\text {th }}-15^{\text {th }}$ centuries, particularly the changes in personnel and in competences of the Pskov princes, the authority and the officials of the princely administration. The article shows the evolution of the sotnia (a hundred unit) organization from the princely one into the republican one. The research reveals Pskov's considerable differences from Novgorod in terms of regulation of commerce and defines the function of the rank-and-file traders' elder in the system of the republican power. The author argues that the Pskov veche functioned as a state institution that had been formed in the course of Pskov's fight for independence in the $13^{\text {th }}$ century. The fact of adopting the documents of taxpaying at the veche assembly reveals the fully institutionalized character of governmental bodies of the Pskov republic. By drawing upon H. J. Berman's argument of independence within European cities of the $11^{\text {th }}-12^{\text {th }}$ centuries, this article contributes to the discussion of Pskov's independence by outlining the main criteria of Pskov's sovereignty. Pskov had a right to issue and supplement laws; the Pskov Judicial Charter arose out of the princes' local charters and was further edited at the veche assembly. Pskov set its own taxes and the veche was empowered to free separate groups of landowners from paying taxes. The rights to military mobilization, to the declaration of war and to making peace, which were under the complete jurisdiction of the republic, undoubtedly demonstrates the sovereignty of Pskov. Finally, the sovereignty of Pskov was manifested in the symbols of stamps and coins that were used in the Pskov republic. All these facts taken together demonstrate the feasibility of applying the medieval European cities' criteria of sovereignty to the Pskov socio-political realties.

Keywords: Prince; republic; sovereignty; borough; elder; deputy; magistrate; posadnik.

Modern historians take a particular view of the nature of the sociopolitical order that developed in Pskov between the thirteenth and fifteenth centuries. That is, like the cities of Italy, Novgorod and Pskov were marked by social and territorial polarization: landowners were concentrated in the towns, while the rural population was deprived of political rights [Сестан, c. 9-40]. This phenomenon is also borne out by the terminology used in contemporary chronicles: even as late as the 1480s, authors labelled Pskov peasants smerdy, even though this term had already disappeared from 
documents in other parts of Russia around the turn of the fifteenth century. The political system based on the veche (public assemblies), which had achieved its most developed form by the fifteenth century, had qualities that sharply distinguished it from the monarchical system of princedoms in Northeast Russia.

In contrast to the prince's power, which was absolute in the political system of the Russian princedoms, the veche-based republics contained structures that complemented and counterbalanced each other. The veche, the posadnik (governor or mayor), the kniaz'-namestnik (the prince's deputy), the sotskie (the hundredmen, i.e, elected leaders of administrative districts), and the vladichniy namestnik (the Novgorod archbishop's deputy) held significant political and legislative powers. The veche had legislative functions. The posadniks, who by the middle of the fourteenth century had formed a collective representative authority based on kontsy (the "ends" or boroughs of the city in which they lived), possessed executive and supreme judicial authority, which they shared with the prince. Both the mercantile affairs court and issues of public services were directed by elected elders (starosty) from among the hundredmen, merchants (gosti), and rank-and-file traders (kuptsy).

This distribution of executive and legal powers ensured the collegial character of legislative and administrative activity. Apart from the institution of the posadniks, which was oligarchic in its composition, the middle layers of the urban population were included in the processes of governance and the administration of justice: for instance, representatives of the zemtsy (private landowners) occupied the posts of hundredmen and archbishop's deputy; merchants held the posts of merchant and trader elders; and chornye liudi (the lower classes) elected ulichanskie (street) elders. Lawrence Langer has shown that by the 1460s the hundredmen did not participate in diplomatic negotiations, which highlights the reduction of their role in the governance of Pskov [Langer, p. 58].

Historians have not resolved, however, a number of problems. First, it is not completely clear what the prerogatives of the various branches of power in Pskov were. How great were the prince's powers, and how did they evolve? How did the prerogatives of the posadniks correlate with these powers? What were the functions of the veche? It is of no small importance that acquisition of full authority by these state institutions was closely linked to the process by which Pskov gained sovereignty and separated from Novgorod. A second vital question is whether, despite the oligarchic nature of the power held by the posadniks, it is possible to define the system of governance in Novgorod and Pskov as republican.

An essential feature of Pskov's political system was that princely authority arose concurrently with the process of gaining independence; in contrast, the prince existed from the outset in Polotsk and Novgorod. Later, the power of the prince in Pskov increased or weakened as a kind of reflection of other institutions in the boyar republic. The chronicle tells us about the only prince, Sudislav, who was enthroned until the second quarter of the $12^{\text {th }}$ century. He was arrested in 1036 by order of the Grand Kiev 
prince. It is not inconceivable that there were other princes in Pskov. Nevertheless, the data about Pskov in the first Novgorod chronicle appeared only in 1132 when its compilation fell under the archbishop's control [Гиппиус, c. 41]. The prince's system of governance in Pskov passed through two periods. The first period, lasting from 1137 up to 1399 , contained 24 princes in Pskov's office, among whom exist two status groups.

The first group includes independent dynasts, applicants to the princely throne (kniazheskii stol) who did not recognize the power of Novgorod and its princes: Vsevolod Mstislavich (1137-1138) and Alexander Mikhailovich Tverskoi (1327-1337). Clearly the period they held office in Pskov occurred simultaneously when there were no peaceful relations with Novgorod. The second group was comprised of junior members of princes' dynasties who usually fulfilled the functions of their senior sovereigns' deputies. If the head of the dynasty possessed a princely throne in Novgorod, he supervised the Pskov deputy, thereby causing Pskov to fall under Novgorod control. Thus, the Novgorod prince, Mstislav Rostislavich, placed his son Boris on Pskov's princely throne after conflict with and removal of the Pskov sotskii (hundredman) [Полное собрание русских летописей, 2001, с. 608]. Prince Mstislav Udaloi, who captured Novgorod in 1209, placed his brother Vladimir on the Pskov throne, and Vladimir's dependence is shown by his various transfers from Pskov to Velikie Luki, then back to Pskov [Новгородская первая летопись, с. 51-52].

Research into the custom of the "donation" (dar) presented to princes has shown that Pskov and the grand princes of Vladimir (descendants of Alexander and Andrei Yaroslavich) were united by this tradition, which developed in the middle of the thirteenth century and continued on into the fourteenth and early fifteenth centuries. As mentioned in the chronicles, the donation was understood to be an irregular and quantitatively nonfixed payment to representatives of the Suzdal and Moscow princely dynasties. The donation could be presented either to a sovereign ruler (for example, Ivan III) or to his vassal - for example, Prince Shuisky, who was likewise among the descendants of the Yaroslavichi princes. The tradition of offering the donation continued until Pskov was incorporated into the Russian state, and the size of the donation in monetary terms could have been as much as 150 rubles, which can be characterized as a symbol of vassalage, but not as a significant source of income. This enduring political tradition (1242-1510) shows that Pskov undoubtedly was among those lands controlled by the Vladimir-Suzdal dynasts, whose military, political and religious influence in Pskov determined its geopolitical orientation [Аракчеев, 2004, с. 39-62].

The fourteenth century was a time when the Grand Duchy of Lithuania dominated Eastern Europe. Valentin Yanin has shown that in 1326 Lithuania concluded an agreement with Novgorod by which it inherited from the Smolensk princes the right to Novgorod's southern lands (the chernokunstvo). Earlier, Vladimir Monomakh had transferred these lands to Novgorod to provide for his descendants, who possessed a princely 
throne (kniazheskii stol) in the veche-governed city [Янин, 19986, с. 57]. Seven years later, in 1333, Prince Narimantas (Gleb), son of the Lithuanian Grand Duke Gediminas, appeared in Novgorod and received Ladoga, Oreshek, Korela, and half of Koporye to tax for his own use [Новгородская первая летопись, с. 345-346]. In 1341, the Grand Duke Algirdas came to Pskov at the head of the army that had repulsed the attack of the Livonian Germans, and he placed his son, Andrei, on the city's princely throne. Along with Lithuanian "collector" princes, dynasts from Polotsk, Andrei and Ivan Andreevich, reigned in Pskov from 1341 to 1399. The time of the Lithuanian princes' ruling in Pskov coincided with the time of Pskov getting its independence from Novgorod. Nevertheless, Pskov, in the same way as Smolensk, did not remain under Lithuanian control. Pskov fell under Moscow's influence as directed by the Treaty of Salynas between Livonia and Lithuania. Vytautas delivered Pskov to the Order, the Teutonic knights, and removed his deputy from service in Pskov.

At the same time, princely power was redoubled by the emergence of its suzerain: outside Pskov's boundaries first, the grand duke of Lithuania, and later the grand prince of Moscow. At first, princely authority and governance in Pskov appears to be similar to Novgorod. However, in contrast to Novgorod - where the prince was represented by his deputy, who did not always possess a princely title - in Pskov the deputy of the grand dukes of Lithuania or the grand princes of Moscow was personally enthroned at the Holy Trinity Cathedral and participated in diplomatic negotiations. In 1467, the Pskov princes, who were themselves deputies of the Moscow grand prince, gained the right to have their own deputies in all twelve suburbs of Pskov [Псковские летописи, с. 164]. In the second period there were 26 princes on the Pskov throne, from different dynasties of Northeast Rus (Tver, Rostov, Suzdal princes) as well as of Lithuania (A. V. Chertorizhskii). None of them demonstrated political independence by occupying the position of the prince-deputy.

Apart from the above mentioned deputies in the suburbs, the Pskov Judicial Charter indicates the prince's officials who fulfilled missions for the court (bailiffs) and the prince's people (kniazheskie liudi). Of interest is the relationship between the princely power, Pskov hundred units (sotni), and hundredmen (sotskie). The sotskie in Pskov existed since 1179, when prince Mstislav Rostislavich entered Pskov (Pleskov) and removed the sotskie that had been appointed by his son Boris [Полное собрание русских летописей, 2001, с. 608]. A.V. Valerov interprets these events by asserting that Pskov was independent from Novgorod at the end of the $12^{\text {th }}$ century. In Valerov's view, sotskie were the leaders of administrative districts that were removed by the Novgorod prince [Валеров, с. 130].

Valerov's stance, however, produces several contradictions. The thesis about Pskov's sovereignty in the $12^{\text {th }}$ century is untenable, because evidence demonstrates Pskov's dependence upon Novgorod. Indeed, V. A. Kuchkin's research shows that sotskie and sotni in Novgorod and Pskov were subject to the prince's authority. This was the reason for prince Mstislav's entrance 
into Pskov, where the population was unfriendly to him, and removing the sotskie that had been appointed by Mstislav or his predecessors.

The institution of sotskie in Pskov differed dramatically from that of Novgorod, which was headed by a tysiatskii (a thousandman). Why was there no thousandman in Pskov? If Pskov during $12^{\text {th }}-13^{\text {th }}$ centuries was considered a part (sotnia - a hundred unit) of Novgorod, then it would have been symbolically represented by a tysiacha (a thousand unit). Can such a hypothesis be supported? In the Novgorod "Charter of Bridges" of the 1260s the authors enumerated the sections of the Great Bridge across the Volkhov-river. The sections were being built from the funds of the Novgorod sotni and countryside communities (volosti). Among 10 sotni, only the first 9 were called by the names of the sotskie, whereas the $10^{\text {th }}$ hundred unit (sotnya) was called "kniazhia" (that of prince) [Российское законодательство, с. 236-237]. L. A. Bassalygo suggests his own version of the problem of the power parity between the tysiatskii and the prince's sotnya, arguing that they were under the prince's jurisdiction as well as the other 9 sotni [Бассалыго, с. 48-51].

V. L. Yanin thinks that the sotskie of the prince's sotnya did not submit to the Novgorod tysiatskii because their identifying object was the stamp with the inscription, "The Grand Prince’s Chiune” [Янин, 1998 a, с. 95-96]. The $10^{\text {th }}$ sotnya of the Novgorod tysiacha stood for Pskov, which was a part of the Novgorod Republic until it gained independence. Interestingly, while Pskov was gaining sovereignty at the end of the $13^{\text {th }}$ century to the first half of the $14^{\text {th }}$ century, the idea of Pskov as the $10^{\text {th }}$ sotnya of the Novgorod tysiacha disappeared from the sources. "Vsevolod's Charter" about the church courts, which was compiled at the end of the $13^{\text {th }}$ century, mentioned 10 sotskie without any reference to the prince's sotnya [Российское законодательство, с. 250].

While Pskov was gaining sovereignty, its sotskie were moving out from under the Novgorod thousand man's authority, but at the same time they did not place themselves under the Pskov princes' authority. Their participation in solving foreign policy issues and land conflicts testifies that the Pskov sotskie in the $14^{\text {th }}-15^{\text {th }}$ centuries represented the city of Pskov and its residents. Indeed the sotskii are mentioned in the Right Certificate in 1483. Due to Article 78 of the Pskov Judicial Charter, princely official (kniazhoi boyar), Mikhail Chet, and sotskii, Klimeta Semionovich, were sent to witness the measure line examination [Грамоты, с. 327].

Thus, to the prince's deputies in the $14^{\text {th }}$ century Pskov appeared to be an exterior power that was deprived of the support of the sotni. However, as distinct from Novgorod where sotni were incorporated into the boyars' boroughs (kontsy) in Yanin's opinion, Pskov's sotni retained some independence from the kontsy and the posadniks that headed them. This explains the differences in Novgorod's and Pskov's socio-political organization, as the diminished role of posadniks' oligarchy and the increased role of the unprivileged population, typified the political life of the latter. 
The most influential part of the unprivileged population, kuptsy (rankand file traders), created their own organization no later than mid- $14^{\text {th }}$ century. The organization was headed by the kuptsy's elder who came from the boyars. B. N. Floria discovered the similarity of this official with the Novgorod tysiatskii, whose post in the $14^{\text {th }}$ century was also usurped by the boyars [Флоря, с. 52-55]. This is the only similarity between the Pskov kuptsy's elder (starosta) and the Novgorod tysiatskii. The Pskov kuptsy's starosta did not possess the prerogatives of the mercantile affairs court, which was in hands of gospody (the highest judicial body that consisted of the prince, posadnik (governor or mayor), and the sotskii.

The institution of kuptsy's elders (starosty) was indirectly linked to the Pskov original church organization, sobory (councils) of the parish clergy. B. N. Floria showed that kuptsy's storosty of Trinity Cathedral initiated the building of St. Sofia Church, the head of which appeared with the second council of clergy in 1357 [Ibid.]. St. Sofia Church became the patron temple of the Pskov rank-and-file traders union, which was headed by the starosty from posadniks' families - Yuri Vinkov, Yakov Krotov, and others. That is why the interpretation of the Pskov sobory phenomenon more recently faces objections by A. E. Musin. He regards sobory (clergy's councils) as the structures related to the sotni of the Pskov posad, considering that sobory were of "community and sotni's character" [Мусин, c. 187-192]. He does not agree with A. Nikitskii's and T. B. Kruglova's claims about the subordinate position of church to the secular governmental bodies, and he ignores the above mentioned facts of the starosty's patronage over St. Sofia Cathedral.

I maintain that although the sobory of clergy in Pskov bore an outward resemblance to the seven sobory of Novgorod, they differed from the Novgorod councils in their essence. By lacking a vladichnaia kafedra (the archbishop' chair) in Pskov, and having a Pskov resident on the post of vladichniy namestnik (the archbishop's deputy), Trinity Cathedral starosty's control over the sobory of clergy undoubtedly fostered some autonomy of Pskov parishes within the Novgorod Eparchy. The evidence for this exists also in the famous attempts of Pskov to withdraw from subordination to the Novgorod archbishop, which resulted in establishing the Eparchy in 1589.

Unlike the princely authority, the Pskov veche is mentioned in written sources (primarily in the chronicles) only in the fourteenth and fifteenth centuries. Does this mean that veche assemblies did not exist in Pskov during earlier times? Such a conclusion would be hasty and unfounded, for the difference between the kinds of events mentioned in the Pskov chronicles for the thirteenth century, on the one hand, and the fourteenth and fifteenth centuries, on the other, is much too significant. Following the work of H.-J. Grabmüller, the original manuscript of the Pskov chronicles drew on two sources: annals covering a broad panorama of foreign policy events and a regional chronicle steadfastly focused on events in the republic's internal political history [Grabmuller]. 
Assuming that the absence of information about the Pskov veche in the chronicles for the twelfth and thirteenth centuries is explained by the specific nature of their origins and accepting as a hypothesis that the Pskov veche existed during these centuries, signs of its activity can be detected within the context of other political events. For instance, there is the chronicle entry about the Pskovians and Ladogans, who took part in the Novgorod veche in 1136 that banished Prince Vsevolod Mstislavich from Novgorod. If veche assemblies were held in Pskov synchronously with this event, their standing was incomparably lower than that of the Novgorod veche. Having provisionally concluded that not every assembly is a veche, there were singular issues discussed in the Pskov veche during the $15^{\text {th }}$ century and during earlier times.

There are sixty-six mentions in the chronicle of veche meetings in the latter part of the fifteenth century. The veche fulfilled purely representative functions, approving the transfer of the "donation" to the prince, confirming the results of embassies, and appointing military leaders. In most cases, the veche apparently had no alternatives to choose from. In all the cases mentioned, the reports made by ambassadors were formal in which the members of the veche were informed about the decree of the suzerain, the grand prince of Moscow. The decision to grant a "donation" to the descendants of Alexander Nevsky also did not break with Pskovian custom. Only with the appointment of military leaders can the hypothesis be made that there were alternative candidates to choose from, but there is no evidence that this was the case. There are, however, reports of harsh political struggles in which the veche found itself entangled. In the late summer of 1462, Prince Vladimir Andreevich was not permitted to assume the princely throne: "The ignorant Pskovians, evil people, pushed him off the rostrum [stepen']" [Псковские летописи, 1955, с. 150]. In this case, the rostrum in question is obviously the rostrum at the veche.

The veche and its decisions played no small role in the events in Pskov of 1483-1486. On June 13, 1484, the posadnik Gavriil was killed "by all of Pskov at the veche": apparently, he had been accused of substituting a certain deed (gramota) without sanction from the city. In the winter of 1484-1485, an embassy of posadniks and boyars reported twice to the veche about the results of their trips to the grand prince. In the summer of 1485 (after Saint Peter's Day), members of a third embassy (led by Ivan Agafonovich) communicated the grand prince's reply to Pskovians at the veche: he ordered that a verdict against the posadniks be annulled and that certain peasants be freed.

To resolve a conflict, posadniks participated in a fourth embassy to Moscow, and they also reported back to the veche. Finally, participants of a fifth embassy to Moscow, in a case involving peasants, reported back to the veche on July 8,1486 . In the chronicle, entries on the events of $1483-$ 1486, show that opposition exists between two groups: on the one hand, the posadniks, boyars, and zhit'i liudi (a kind of proto-middle class), and on the other, the chernie molodshie liudi, the "black younger people", or the 
city's lower class [Псковские летописи, 1941, с. 62, 79, 80; 1955, с. 65, 69]. As Yuri Alexeev has rightly noted, "The 'black people' [lower class] retained the right to participate in the veche assembly; what is more, they apparently constituted the main contingent at the assembly" [Алексеев, с. 269].

Taken together with the above mentioned facts, Y. Granberg concludes that the veche assembly was an ordinary gathering of the city residents of the city community - and it did not possess the features of a political institution [Гранберг, с. 3-149]. Yet Y. Granberg did not investigate all the veche's appearances in the written sources. One of the deeds published by L. M. Marasinova escaped his attention. The deed dates back to the end of the $15^{\text {th }}$ century and indicates the Trinity Cathedral community's release from paying taxes. The document unambiguously testifies to the active role of the veche in solving problems of landowning and taxpaying. This decision to free the community from paying taxes was approved by the Pskov veche [Марасинова, с. 72]. One more document confirming that the veche in Pskov was a political institution is a letter of grant of 1308-1312, which was also given by the will of Master Grand Pskov at the veche assembly. Importantly, when did the veche achieve this institutional character?

Extrapolating conclusions about the veche's functions in the latter half of the fifteenth century to an earlier period, it is possible to see its involvement with the first foreign treaty known from the chronicles: a mutual assistance treaty with Riga that Pskov concluded in 1228 [Новгородская первая летопись, с. 66]. Despite the fact that the sources mention no corresponding decision on the part of the veche, the Pskov diplomats, who concluded the treaty, would have had to poslovat' posol'stvo, that is, report on the results of their mission, to the veche. Perhaps it is unfounded to hold the assumption that the veche emerged at a very late period in Pskov?

Comparing veche-based governance in Pskov with that in Novgorod, a phenomenon exists which is difficult to explain at first glance. As Yanin has shown, the integral feature of Novgorodian statehood was federalism. Novgorod arose as a federation of settlements and developed in the fourteenth and fifteenth centuries as a political entity by means of compromises and conflicts between boyars from its various boroughs or "ends," which had grown out of these tribal settlements. With the exception of the latter Zagorodsky borough, which was artificially created in the 1290s to double the representation of boyars from the Liudin borough in the city collective governance bodies, the other districts in Novgorod arose early on and had acquired their final shape by the eleventh century at the latest. The borders of Novgorod's boroughs remained unchanged throughout the fourteenth and fifteenth centuries. The boyars in the Novgorod boroughs represented clans that were united by kinship ties and engaged in an intense struggle for power [Янин, 2008, с. 160-162].

In contrast, there does not appear to be independent political action on the part of Pskov's boroughs. Known Pskov posadniks cannot be confidently assigned to one or another borough, and there is no record in the sources of conflicts between the boroughs. The existence of the 
boroughs is recorded for the first time in the chronicles in the mid- $14^{\text {th }}$ century, which gives the impression that they were artificially created on the site of a single urban entity. Their configuration also testifies to this fact. They extended in a radius from the walls of Dovmont's Town (the citadel) to the Pskov posad (i.e., the settled area outside the city's Kremlin). Their brief existence demonstrates the same. As early as the fifteenth century, these boroughs, which were essentially blocks separated from one another by city streets, gave way to compact city districts, which sometimes retained the word borough (konets) in their names: Sredny Gorod, Petrovsky Konets, Polonissky Konets, Bogoyavlensky Konets and Kuzmodemiansky Konets (which merged into Zapskovsky Konets), and Zavelitsky Konets, which is only sporadically mentioned in the sources.

Judging by later sources from the latter half of the sixteenth century, each borough had an elected administration, an institution that received a new lease on life after the zemskaia (land) reform of Ivan the Terrible. In spite of its essentially fiscal functions, the zemskaia administration, in the persons of the borough elders (konchanskie starosti), money collectors, and clerks (d'iachki), clearly inherited certain qualities from the borough administrations of the republican period [Аракчеев, 2006, с. 3-11]. But if the Pskov boroughs arose only in the process of territorial expansion, then they would have had their origins not in federalism but in monocentrism, which would have been conceivable in two cases: if a strong monarchical authority was present, or if the city was controlled from elsewhere. Since the Pskov princes did not show autocratic tendencies, then it appears that Pskov's veche-based statehood developed under Novgorod's direct influence right up until the mid-fourteenth century. This means that the forms in which popular public activity were manifested before the early thirteenth century could not be interpreted as state assemblies because only the veche in the capital city, Novgorod, had this status.

In his work A. E. Musin shows that his stance on the essence of the Pskov veche approaches Y. Grinberg's definition. Musin introduces the notion of "non-institutionalized democracy", implying that the city community is empowered to govern, whereas the source of this power, the veche, was not its institution [Мусин, с. 315-317]. Neither the notion of "noninstitutionalized democracy" nor its grounds can be accepted due to an array of reasons. The concept of "institution" for historians means any longoperating establishment or phenomenon. In this respect historians of law say, for instance, that blood revenge represents an institution of a customary law. The Pskov veche, then, whose activity was reflected in documents marking its decisions and appearing on the pages of chronicles, undoubtedly possessed the features of the state institution.

Arguably then the entry for 1228 in the Novgorod First Chronicle records at the very least the Pskov veche's first step towards its transformation into an organ of the city-state's sovereign authority. This step did not in any way signify that Pskov had achieved its independence, which could not simply have been declared but would have been obtained only after its recognition by 
the metropole. Relations between Pskov and Novgorod passed down a long and difficult road between 1228-1348, which included periods both of local separatism and of recognition of either the sovereignty of Novgorod or the great princes over Pskov. The first period of self-proclaimed independence was 1228-1242, when Pskov attempted to pursue an independent policy, which ended with its temporary annexation by the Livonian Order.

After the victorious battle of April 5, 1242 (the so-called Battle of the Ice), Pskov once again pronounced its fealty to the great prince and to Novgorod, as witnessed by a reference in the chronicle to an agreement declared by Alexander to the city's authorities [Псковские летописи, 1955, с. 21]. Pskov's political subordination to Novgorod was reflected in foreign policy when, in May 1269, representatives of the metropole concluded a peace with the Livonian Order, na vsei voli novgorodskoi, agreeing upon terms dictated by Novgorod [Новгородская первая летопись, с. 87]. A second armed conflict (razmir'e) with Novgorod and the great prince, between 1328-1329, ended with the peace treaty signed in Opoki [Новгородская первая летопись, с. 99]. On May 27, 1341, Pskov invited the Lithuanian Grand Duke Algirdas to reign; according to the chronicle, the Pskovians had "betrayed themselves" (predashasia) to Lithuania [Ibid., c. 354]. The Bolotov Treaty (which scholars variously date between 1329 and 1342) finally defined Pskov's claims to sovereignty, which were confirmed by the Novgorodians. They agreed that in Pskov posadniks from Novgorod would no longer be appointed or have judicial powers there, that the local ecclesiastical court would be administered by a representative of Pskov, and that Pskovians would not have to appear in court at a summons from Novgorod bureaucrats [Полное собрание русских летописей, 2000, с. 278].

The claim about Pskov's independence from Novgorod between the late fourteenth and early sixteenth centuries largely has not been questioned by historians. The only exception is V. A. Burov, who writes: "The term 'independence,' as used by historians, does not always reflect the essence of the phenomenon. It implies an anachronism; it modernizes medieval societal relations. The Pskov Land was independent only in terms of selfadministration. But it was never independent from Novgorod. Novgorod and Pskov demonstrate a special type of vassalage in Eastern Europe in which city-states led by princes played the roles of vassal and suzerain. Precisely for this reason, in the text of the 1471 treaty between Novgorod and Casimir it is noted that in Pskov there existed 'the court and the seal and the lands of Novgorod the Great [...] in accordance with tradition.' If Pskov were completely independent, the document would not have mentioned this at all" [Буров, с. 141]. Yanin has responded to Burov's argument by noting that the court and lands of Novgorod the Great, cited in the treaty, belonged to the archbishop of Novgorod [Янин, 1993, с. 220]. However, Burov countered that the treaty of 1471 mentions the court, the seal, and the lands of Novgorod, not those of the archbishop [Буров, с. 142].

Does this mean that Pskov was never really an independent state, or that it possessed only the rights of self-administration within the Novgorod 
federation? What kind of state can be considered sovereign? What are the criteria of independence? Harold J. Berman writes that European cities of the eleventh and twelfth centuries were "modern states" when they had "full legislative, executive, and judicial power and authority, including the power and authority to impose taxes, coin money, establish weights and measures, raise armies, conclude alliances, and make war" [Berman, p. 395].

Berman's definition can be used to elucidate whether or not Pskov possessed aspects of sovereignty. The first criterion of independence is the enactment of laws by sovereign state institutions. The law code of medieval Pskov - the Pskov Judicial Charter (Pskovskaia Sudnaia Gramota) developed over a long period and did indeed begin with a princely decree (pozhalovanie) by the Great Prince Alexander. But in the mid-thirteenth century Pskov was still part of the Novgorod Republic, and naturally the sovereign ruler of Northern Russia, Alexander Nevsky, promulgated a document to the Pskovians dealing with the prerogatives of the princely law court. However, both the Pskov Judicial Charter's first redaction, of 1397, and its last redaction, of 1460 , were ratified at the veche, as was unambiguously declared in the preamble, and this is doubtless a sign of the sovereignty of the republican authority, the Pskov veche. As Berman writes, this "systematization of ordinances and laws by the governing bodies of the city or town" reflects "the system of urban law ['s] capacity for growth $<\ldots>$ its tendency $\langle\ldots\rangle$ to develop continuously and organically" [Berman, p. 397].

A second criterion of independence is an empowered position to set taxes. And there exists a document demonstrating the right of the Pskov veche to set taxes or not set them: the deed at the end of the 15th century that freed Trinity Cathedral community from taxes [Марасинова, с. 72]. The third criterion, minting, is satisfied when Pskov started making coins in 1425 [Псковские летописи, 1955, с. 39]. The image of prince DovmontTimophey analogous to the image on the Pskov stamps of 1424/25 and 1468/69, was coined on the Pskov money [Белецкий, с. 330]. The prince's presence on the stamps and on the coins undoubtedly shows that the residents of Pskov recognized them as representing their state's independence. The forth and the fifth criteria include summoning troops, forming alliances and declaring wars. These have been demonstrated and are well-known.

In addition to Berman's criterion of independence, there exists also the right to use state seals when handling documents. The fact that Pskov used republican seals to ratify international treaties also supports the claim of Pskov's sovereignty. Moreover, the lead seals of the Pskovian state have been preserved, and just like the corresponding articles in the Pskov Judicial Charter, they demonstrate that the republic's state institutions had equal jurisdiction. Article 50, which established the equal legal force of the princely and Troitsky (that is, the veche's) seals, states: "And the prince's scribe takes [as his fee] for writing up a summons, or a default judgment charter, or a bailiff's document what the litigant is able to pay; if he wants more than [the litigant] can pay, then [the litigant] is free to have someone else write up [the document], and the prince is to affix his 
seal; if the prince will not affix his seal, then obtain the seal at the [Pskov archives in the] Holy Trinity Cathedral, and there is no irregularity in this procedure" [Российское законодательство, с. 336]. These criteria taken together show that the Pskov republic was a sovereign state between 1340 1510. The only area in which Pskov partially relinquishes its sovereign rights is forming alliances; from 1468 alliances were supported by Moscow.

Perhaps the most complicated question (as mentioned in the 1471 treaty between Novgorod and Casimir) is that of "the court and the seal and the lands of Novgorod the Great". Burov persuasively counters that this fragment refers only to the prerogatives of the Novgorod archbishop in Pskov. As we know, beginning in the mid-14th century the archbishop of Novgorod was represented in Pskov by his deputy, whose prerogatives were limited to the ecclesiastical law court. He thus used a seal derived from the archbishop's seal in his work. However, information about lands in Pskov under the archbishop's jurisdiction is missing; nevertheless, the text of the treaty provides some details on the origin and nature of the lands in question.

The article about Pskov in the treaty is part of a fragment in which the first and last sentences deal with relations with the great prince of Moscow:

In [the town of] Torzhok your deputy [tiun, the deputy of the Lithuanian grand duke] is to judge in court [along] with the Novgorod posadnik, and in Volok [Volokolamsk] as well, in accordance with Novgorod court [customs], and the fees, [for] the wergild and wager by battle, [are to be imposed] in accordance with Novgorod court [customs]. And [the rights] to the court and the seal and the lands of Novgorod the Great in Pskov will be returned to Novgorod the Great, in accordance with tradition. If you, honest lord and king [the Lithuanian grand duke], compel the [Moscow] great prince to make peace with Novgorod, then you, honest king, are to have the right to exact the cherny bor [a special tax] from the Novgorod lands [volosti], in accordance with tradition and the old deeds, once, but in other years [in future] [the tax] will not be required [Грамоты, с. 132].

This fragment demonstrates a well-known feature of medieval contracts and agreements: the sequential assertion of identical problems via the articles of such agreements. Insofar as Torzhok and Volok had been under the joint jurisdiction of the grand prince of Vladimir and the republican authorities since the thirteenth century, Casimir's desire to maintain his own representatives encroaches on Moscow's prerogatives. The right to exact the cherny bor from the Novgorod lands also belonged to Moscow, and Casimir obviously wanted to redirect the tribute to his own advantage. Consequently, if the treaty states that the court, the seal, and the lands of Pskov should revert to Novgorod in "accordance with tradition" (po starine), requital on a third party, i.e., Moscow, is implied here as well.

Assuming that the Novgorodian lands in Pskov had some connection with the rights of the great princes, then we should ask what sort of court, seal, and lands Moscow might control in Pskov in 1471. The court at this 
time was under the control of the princely deputies, and the state seal of Pskov was the "seal of the Pskov [patrimonial] lands of the Moscow great prince" (pechat' pskovskaia votchini velikogo kniazia moskovskogo) of 1468/69 [Белецкий, с. 330-331]. At this time, the lands were the former state lands of Novgorod, from which the Pskovians collected taxes to finance military expenditures as late as 1464 . The status of these lands is shown by the well-known "dispute over peasants" (brani o smerdah). Whereas in 1464 the Pskovians had tried to vindicate themselves before the archbishop for not sending the tribute, in 1483-1486 the grand prince of Moscow unceremoniously interfered in the process of exacting tribute from the Pskovian peasants. Apparently, during an undetermined period from 1464 until 1471, the right to control these lands, including use of the tribute exacted from the peasants, passed to the grand prince.

So what goals were Novgorod and Casimir pursuing vis-à-vis Pskov? Moscow princely deputies with judicial authority appeared in Pskov in 1399. This means that the return to the previous order of the fourteenth century implied certain prerogatives for the Novgorod law court in Pskov and that the status of the princes was that of "service" (sluzhilyi) princes, like the Koporyean princes in Novgorod. The concept of the patrimonial (votchina) lands of the grand prince was applied in relation to Pskov beginning with the treaty of 1417, although a corresponding seal exists only from 1468/69 on. A return to the previous regime of seals would have meant a return to the "pre-patrimonial" seal, which at very least symbolized Novgorod's partial sovereignty over Pskov.

What category of seals could correspond to this status? In the attribution of seals to Pskov's state institutions undertaken by S. V. Beletsky, there is a significant gap [Белецкий, c. 327-339]. It is completely unclear what seals might have been used in Pskov during its existence as part of the Novgorod Republic, which might have symbolized the idea of Novgorod's sovereignty over Pskov. A return to the previous order in land ownership could have meant that the former Novgorod lands were removed from the control of the Moscow princely deputies and returned to the management of deputies from the Novgorod Republic. Thus, the court, seal, and lands of Novgorod the Great, as mentioned in the draft of the 1471 treaty between Novgorod and Casimir, do not indicate Pskov's dependence on Novgorod, as Burov claims. On the contrary, Novgorod's dominant position in Pskov "according to tradition" had been lost irretrievably by that time, and the Novgorod Republic attempted to reseize this dominance.

Proof of Pskov's independence from Novgorod during the late 14th and early 15th centuries does not resolve one other issue that confronts research on the republic's sovereignty: its relationship with and degree of dependence on the great prince of Moscow. Beletsky argues that from 1468 to 1510 Pskov was "a protectorate of the Great Prince Ivan III Vaslievich" [Белецкий, с. 327]. The term "protectorate," which emerged in seventeenthcentury England and was employed actively during the colonial age, contains connotations that detract from its usefulness in describing the 
realities of the medieval age. Moreover, the term implies that the metropole is responsible for the foreign relations and defense of the dependent territory. In the late fifteenth and early sixteenth centuries, Pskov relied on the support of the great prince of Moscow when it needed defence against the Livonian Order, but the conclusion of treaties with the Order, which were implemented "according to the will of the tsar and sovereign of all Russia," were the prerogative of the Pskov magistrates [Казакова, с. 91].

A comparison of Pskov with the cities of Western Europe during the fourteenth and fifteenth centuries shows that its status more closely resembles cities of the Hanseatic League, which include Rostock, which was under the jurisdiction of the Mecklenburg dukes, although "all economic, administrative, and political power was in the hands of the magistrate" [Пoдаляк, с. 66]. At the same time, Pskov's status cannot be compared to that of the city-states of Northern Italy, which were in the process of liberating themselves from the power of feudal overlords.

Алексеев Ю. Г. «Черные люди» Новгорода и Пскова: к вопросу о социальной эволюции древнерусской городской общины // Исторические записки. 1979. Т. 103. C. 242-274. [Alekseev Yu. G. «Chernye lyudi» Novgoroda i Pskova: k voprosu o sotsial'noj evolyutsii drevnerusskoj gorodskoj obschiny // Istoricheskie zapiski. 1979. T. 103. S. 242-274.]

Аракчеев В. А. Средневековый Псков: власть, общество, повседневная жизнь в XV-XVII вв. Псков, 2004. [Arakcheev V. A. Srednevekovyj Pskov: vlast', obschestvo, povsednevnaya zhizn' v XV-XVII vv. Pskov, 2004.]

Аракчеев B. А. Земская реформа XVI в.: общероссийские тенденции и региональные особенности // Отечественная история. 2006. № 4. С. 3-11. [ V. A. Zemskaya reforma XVI v.: obscherossijskie tendentsii i regional'nye osobennosti // Otechestvennaya istoriya. 2006. N 4. S. 3-11.]

Бассалыго Л. А. Новгородские тысяцкие // Новгородский исторический сборник. Вып. 11(21). С. 33-67. СПб., 2008. [Bassalygo L. A. Novgorodskie tysyatskie // Novgorodskij istoricheskij sbornik. Vyp. 11(21). S. 33-67. SPb., 2008.]

Белецикий С. В. Сфрагистика / Специальные исторические дисциплины. СПб., 2003. C. 248-367. [Beletskij S. V. Sfragistika / Spetsial'nye istoricheskie distsipliny. SPb., 2003. S. 248-367.]

Буров В. А. Очерки истории и археологии средневекового Новгорода. М., 1994. [Burov V. A. Ocherki istorii i arkheologii srednevekovogo Novgoroda. M., 1994.]

Валеров А. В. Новгород и Псков : очерки политической истории XI-XIV вв. СПб., 2004. [Valerov A. V. Novgorod i Pskov : ocherki politicheskoj istorii XI-XIV vv. SPb., 2004.]

Гиппиус A. A. К истории сложения текста Новгородской первой летописи // Новгородский исторический сборник. Вып. 6(16), с. 3-72. СПб., 1997. [Gippius A. А. K istorii slozheniya teksta Novgorodskoj pervoj letopisi // Novgorodskij istoricheskij sbornik. Vyp. 6(16), s. 3-72. SPb., 1997.]

Грамоть Великого Новгорода и Пскова. М.; Л., 1949. [Gramoty Velikogo Novgoroda i Pskova. M. ; L., 1949.]

Гранберг Ю. Вече в древнерусских письменных источниках: функции и терминология // Древнейшие государства Восточной Европы. 2004. Политические институты Древней Руси. М., 2006. С. 3-149. [Granberg Yu. Veche v drevnerusskikh pis'mennykh istochnikakh: funktsii i terminologiya // Drevnejshie gosudarstva Vostochnoj Evropy. 2004. Politicheskie instituty Drevnej Rusi. M., 2006. S. 3-149.]

Казакова Н. А. Договор Пскова с Ливонией 1509 г. // Вопросы истории. 1983. № 1. C. 90-100. [Kazakova N. A. Dogovor Pskova s Livoniej 1509 g. // Voprosy istorii. 1983. N 1.S. $90-100$.

Марасинова Л. М. Новые псковские грамоты XIV-XV вв. M., 1966. [Marasinova L. M. Novye pskovskie gramoty XIV-XV vv. M., 1966.] 
Мyсин А. Т. Церковь и горожане средневекового Пскова. СПб., 2010. [Musin A. Т. Tserkov' i gorozhane srednevekovogo Pskova. SPb., 2010.]

Новгородская первая летопись старшего и младшего изводов. М.; Л., 1950. [Novgorodskaya pervaya letopis' starshego i mladshego izvodov. M.; L., 1950.]

Подаляк Н. Г. Ростокская соборная распря 1487-1491 гг. / Средние века. Вып. 52. C. 55-75. M., 1989. [Podalyak N. G. Rostokskaya sobornaya rasprya 1487-1491 gg. / Srednie veka. Vyp. 52. S. 55-75. M., 1989.]

Полное собрание русских летописей. Т. 4, ч. 1. М. ; СПб., 2000. [Polnoe sobranie russkikh letopisej. T. 4, ch. 1. M. ; SPb., 2000.]

Полное собрание русских летописей. Т. 2. М.; СПб., 2001. [Polnoe sobranie russkikh letopisej. T. 2. M.; SPb., 2001.]

Псковские летописи, Вып. 1. М., 1941. [Pskovskie letopisi, Vyp. 1. M., 1941.]

Псковские летописи. Вып. 2. М., 1955. [Pskovskie letopisi. Vyp. 2. М., 1955.] 1984.]

Российское законодательство. Т. 1. М., 1984. [Rossijskoe zakonodatel'stvo. T. 1. M.,

Сестан Э. Итальянские города в XIV-XV вв. // Россия и Италия. М., 1972. С. 9-40.

[Sestan E. Ital'yanskie goroda v XIV-XV vv. // Rossiya i Italiya. M., 1972. S. 9-40.]

Флоря Б. Н. Купеческая организация в средневековом Пскове // Восточная Европа в средневековье : к 80-летию В.В. Седова. С. 52-55. M., 2004. [Florya B. N. Kupecheskaya organizatsiya v srednevekovom Pskove // Vostochnaya Evropa v srednevekov'e : K 80-letiyu V.V. Sedova. S. 52-55. M., 2004.]

Янин В. Л. Письмо в редакцию // Отечественная история. 1993. № 6. С. 220.

[Yanin V.L. Pis'mo v redaktsiyu // Otechestvennaya istoriya. 1993. N 6. S. 220.]

Янин В. Л. Актовые печати Древней Руси X-XV вв. Т. 3. M., 1998a. [Yanin V. L. Aktovye pechati Drevnej Rusi X-XV vv. T. 3. M., 1998a.]

Янин В. Л. Новгород и Литва: пограничные ситуации XIII-XV вв. М., 19986.

[Yanin V. L. Novgorod i Litva: pogranichnye situatsii XIII-XV vv. M., 1998b.]

Янин В. Л. Очерки истории средневекового Новгорода. M., 2008. [Yanin V. L.

Ocherki istorii srednevekovogo Novgoroda. M., 2008.]

Berman Harold. Law and Revolution: The Formation of the Western Legal Tradition.

Cambridge, 1983.

Grabmuller H.-J. Die Pskover Chroniken. Wiesbaden, 1975.

Langer Lawrence. The Posadnichestvo of Pskov: Some Aspects of Urban Administration in Medieval Russia // Slavic Review. 1984. Vol. 43, № 1. P. 46-62.

Целью работы является исследование социально-политической организации Псковской вечевой республики в XIII-XV вв. В статье представлен анализ изменений в персональном составе и компетенции псковских князей, изучены полномочия и состав княжеской администрации. Показана эволюция сотенной организации, ее трансформация из княжеской в республиканскую. Обнаружены существенные отличия Пскова от Новгорода в сфере контроля над торговлей; определено место купеческого старосты в системе органов республиканской власти. Приведены аргументы в пользу точки зрения о функционировании псковского веча как государственного института, сформировавшегося в ходе борьбы Пскова за независимость в XIII в. Принятие на вече документов о налогообложении свидетельствует о вполне институциональном характере органов власти Псковской республики. В статье продолжена дискуссия о критериях независимости Пскова. В соответствии с концепцией независимости европейских городов XI-XII вв., сформулированной Г. Дж. Берманом, выделены основные критерии суверенитета Пскова. Псков обладал правом издавать 
и дополнять собственные законы; Псковская судная грамота возникла на основе княжеских уставных грамот, но в дальнейшем редактировалась на вече. Псков устанавливал свои налоги, а вече обладало правом освобождать от налогов отдельные группы землевладельцев. Несомненно свидетельствует о суверенитете Пскова находившееся в безусловном ведении республики право военной мобилизации, объявления войны и заключения мира. Наконец, суверенитет Пскова декларировался в символике монет и печатей, использовавшихся Псковской республикой. Сумма фактов свидетельствует о принципиальной применимости критериев суверенитета средневековых городов Европы к социальнополитическим реалиям Пскова.

Ключевые слова: князь; Псковская республика; суверенитет; конец; староста; представительство; магистрат; посадник.

Vladimir Arakcheev (Владимир Анатольевич Аракчеев), prof., Russia, Yekaterinburg Ural Federal University arakk@rambler.ru 